УДК 339.7

DOI: https://doi.org/10.32782/2413-9971/2019-27-13

\author{
Konstantinova Maria \\ Student \\ Odessa I.I. Mechnikov National University \\ Bychkova Nataliya \\ PhD, Senior Lecturer at Department of World Economy \\ and International Economic Relations \\ Odessa I.I. Mechnikov National University
}

Константінова М. С. студентка

Одеського національного університету імені I.I. Мечникова

Бичкова Н. В.

кандидат економічних наук, доцент кафедри світового господарства

та міжнародних економічних відносин

Одеського національного університету імені I.I. Мечникова

\title{
METHODS OF ASSESSING THE COUNTRY'S INVESTMENT ATTRACTIVENESS
}

Summary. In the context of globalization, the interdependence of countries and the economic gap between them is growing. Thus, there are groups of countries that have an increasing need for foreign investment in various branches of their economics. At the same time, the level of economic attractiveness and industries' readiness for investment vary in developed and developing countries. This is the first reason to continue studying this topic. Moreover, new economic trends are forecasting future crisis, which will take its beginning in America. Shorter US bonds are becoming more profitable than long ones. A similar situation occurred in 2008, 2001, 1990. Inasmuch as a key factor of investment attractiveness is IMF loans, for our country it's very important to estimate a result of this cooperation. And this is the third reason. The presence of IMF in the list of a country's creditors increases its investment attractiveness. Collaboration with the International Monetary Fund suggests that the borrowing country is committed to the principles of a liberal economy, which should attract investors. Since Ukraine has been receiving tranches from the IMF, the country's attractiveness is being discussed. Therefore, there is a need for the correct choice of a country assessment method and factors especially today. In this article, the authors consider existing methods of quantitative measurement and assessment of the economy's investment attractiveness at the micro, meso, and macro levels. The authors consider indicators that are used to assess investment attractiveness at these levels and create a relationship between micro and macro levels. Most part of the research focuses on the macro level. The paper considers factors used by international rating agencies and indexes to assess the investment attractiveness of the country, as well as some practical studies of the factors influence on countries. Based on the factors given as examples, the authors distribute which of them has a positive and negative impact.

Key words: investment factors, country attractiveness, methods of investment assessment, investment, international indexes. 
Formulation of the problem. Studies of investment processes show that there are many different methods of assessing the investment attractiveness of the economy today, which mainly consider its levels separately. There are articles in which the methods are structured by the level of the economy, but not all of them trace the relationship between the factors at the micro and macro levels. Moreover, all the factors are divided into positive and negative, but they do not take into account practical studies which are very important regarding the predicted economic crisis from the USA and uncertain Ukrainian investment attractiveness.

Analysis of recent research and publications. A great contribution to the study of assessment methods at different levels was made by Peter Korenyuk and Elena Kopyl (2018). They analysed factors according to macro and micro levels. There are also many researchers who have studied the influence of specific factors on countries, or a group of countries, for example, Antonios Zairis, Helmut Birnleitner, and others.

Highlighting of unresolved parts of previous studies. Many studies are devoted to reviewing the key influence factors of investments. Thus, Korenyuk and Kopyl (2008) analysed methods and significant factors for assessing the country's attractiveness at the mesa and macro levels. Also, there are practical researches, which prove or refute certain theoretical statements. Demirhan and Masca (2018) considered a huge number of factors analysed by the empirical method by other authors. Based on cross-sectional data, the econometric model was estimated to determine factors of FDI inflows in developing countries over the period of 2000-2004. It should be noted that these two types of researches were not studied and analysed together up to now.

The purpose of the study is to clarify the main methods for assessing the investment attractiveness of countries and to generalize the results of existing theoretical and practical studies for determining the essential factors of the country's investment attractiveness.

Main body. Any investment decision is made on the basis of the analysis of profitability - the return on investment should be higher than the invested capital. Such analysis takes place at the micro level; the investor analyses a portfolio of securities which will be more profitable. At the macro level, the same investor assesses the investment situation in the country and in this case, we rely on experts such as the World Bank Group, Standard and Poor's Rating, and Moody's Investors Services. The attractiveness of the country's economy to investors may be based on the ROI of a particular sector of the economy. With this kind of analysis, it better helps investors to easily understand the financial prowess of every economy.

The above-mentioned methods for assessing any investment portfolio can be divided into three main groups: the statistical approach, the method of expert assessments, and the rating approach.

With the help of statistical indicators, a basic tool to detect the standard of an economy is derived from the statistical approach. This is an easy approach based on reliable data but not all factors can be defined.

According to the expert estimation method, the analyst identifies the most important indicators in his opinion and examines them in the dynamics on the basis of which forms the conclusions. This method adapts to the needs of specific investors and deepens the analysis of the productivity of certain industries. However, such study is subjective and the conclusions largely depend on the position of the expert.

There are two rating approaches: rating-analytical and rating approach based on surveys. The first method analyses the available indicators and their grouping. This method is easy to use and interpret data. A disadvantage is difficulty in choosing the correct methodology for calculating indicators. The second method involves a survey of experts in the region, resulting in a general rating [1, p. 56-62].

Combining these three methods, the macro level analysis of a country takes place. The main indicators can be divided into three groups: general, macroeconomic, and indicators of investment market valuation. The general indicators include data on the competitiveness of the state, the rating on the international investment market. Whiles, there are 40 macroeconomic indicators, which include GDP, government debt, exports and imports of goods and services.

There are several international indexes assessing the productivity of countries. We will analyse some of them. These are the International Country Risk Guide (ICRG), the International Business Compass (IBC), and the Global Competitiveness Index (GCI).

The table above is ICRG's risk assessment indicators for 140 countries. This model is based on estimates of the three components of a country's risk: political (12 variables), financial (5 variables), and economic (5 variables) risks. The political component takes up half of the assessment, while this rating includes such indicators as political imperialization and religious and ethnic tensions. Also, external and internal conflicts are considered. The main economic indicators are GDP per capita, real GDP growth, inflation, budgetary balance, current account, and external debt.

BDO International Business Compass is an annually updated index that measures the productivity level for companies from around the world. The study is published jointly by BDO Germany and the Hamburg Institute of World Economy. This index includes the economic, political, and socio-cultural components, which in turn are combined into the attractiveness of the market and the attractiveness of the place of production.

The main economic indicators of evaluation are: per capita income, national debt, inflation, FDI inflows, tax rate, corruption, per capita spending, etc.

The Global Competitiveness Report (GCR) is an annual report published by the World Economic Forum. The report says that it is based on the latest theoretical and empirical research. It consists of more than 110 variables, two-thirds of which are derived from the Executive Opinion Review, and one-third from publicly available sources, such as the United Nations. Variables are organized in 12 pillars; each column represents an area that is considered as an important competitive factor.

The report includes all possible factors of economic development and assesses the market for goods, finance and labour, its size, innovations, the quality of state institutions, infrastructure, education, and the macroeconomic situation.

Among all the indicators measured by these ratings, there are several main ones: the state budget, external debt, inflation, taxes, national savings, rate, wages

Erdal, Mahmut mentioned in their article "Determinants of a Cross-Sectional Analysis" three types of FDI: market-seeking FDI, resource sourcing and efficiency search [6, p. 356-369].

The first-type investments are focused on local and regional markets. The second type of FDI depends on resources that are not available in the country. According to the third type of FDI, a firm can benefit from the geographically distributed activities with a scale effect.

The most reliable determinant of FDI in econometric studies appears to be market size, as measured by GDP or GDP per capita. Market openness as measured by the ratio of exports and imports to GDP. The size of the Chinese market attracted American and Hong Kong investors. National economists have repeatedly underlined the size of the market and its 


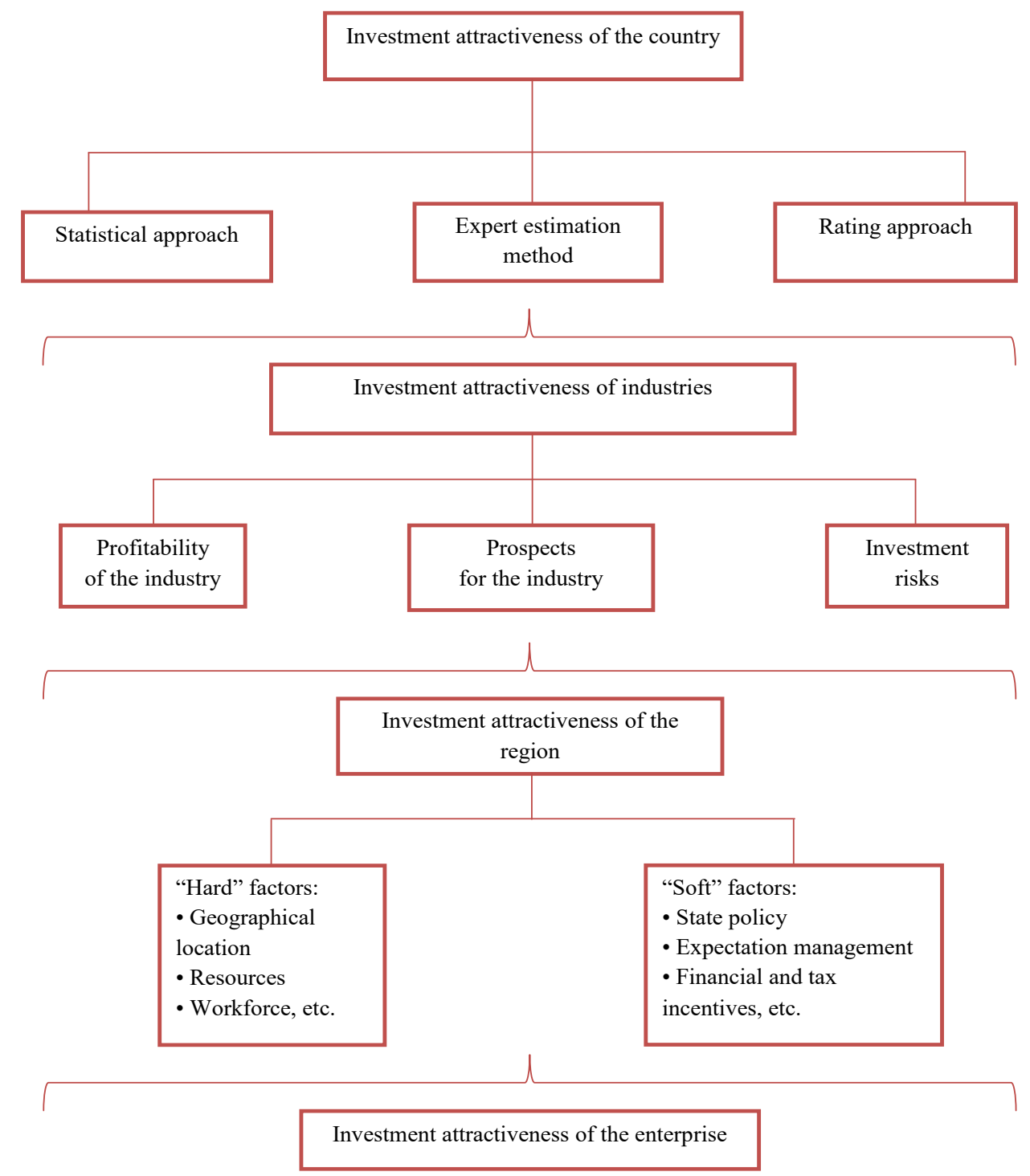

Figure 1. Levels of investment attractiveness of the country

Source: [1, $p$ 56-62; 2, p 235-244]

growth as one of the important factors of the attractiveness of the country [7, p. 21-33].

Wages are the most controversial factor. Theoretically, the cheaper labour force is then more FDI comes to the market. The best example of it is China. Low-wage rates are a key advantage for such industries as automobile assembly and telecommunication equipment [7, p. 21-33]. However, there are a lot of contradicting results of the effect of wages on FDI. The other group of scientists emphasizes a high salary as an indicator of efficiency, especially when highly skilled labour is required [8, p. 48].

Another controversial factor in FDI is political instability. In some situations, it is possible for rich natural resources to be used as a compensating tool for political instability; an example is Nigeria and Angola. Foreign company will continue to invest until it's sure in a profitable work without excessive risk to its capital and staff.

Infrastructure can be seen as an obstacle and an opportunity for foreign investment. Usually, poor infrastructure prevents FDI inflow. But infrastructure remains a potential area to invest if the government is ready to permit it.

External conflicts can have a negative impact on foreign business in many ways, from restrictions on operations to trade and investment sanctions, to distortions in the allocation of economic resources, to violent changes in the structure of society.

Another factor affecting FDI is the spending on R\&D. V.B. Arasha studied the correlation between the annual volumes of both outgoing and incoming FDI, as well as the amount of accumulated outgoing and incoming FDI and R\&D expenditure, calculated at purchasing power parity, for leading countries, as well as the Netherlands and Ireland. According to his research, the correlation was more than 0.8 due to the endeavour of advanced technology countries to invest from one side and their attractiveness to FDI from the other side [9].

Regional integration has a positive impact on investment inflows, for instance, the European Union; or agglomerative economics, such as Silicon Valley. In such associations, costs for certain factors are reduced: for example, taxes, infrastructure, political conditions, etc.

One of the highly controversial factors is the corruption present in an economy. Traditionally, it is assumed that corruption negatively affects investment inflow. However, Lucas (1990) and Haksoon (2010) argue that countries with higher levels of corruption attract more investments from developed countries [10, p. 11-32]. 
Table 1

International indexes of countries' investment attractiveness

\begin{tabular}{|c|c|c|c|}
\hline International Indexes & \multicolumn{3}{|c|}{ Indicators } \\
\hline 1 & 2 & $\begin{array}{r}3 \\
\end{array}$ & 4 \\
\hline \multirow[t]{14}{*}{$\begin{array}{l}\text { International Country } \\
\text { Risk Guide (ICRG) }\end{array}$} & \multirow[t]{12}{*}{ Political Risk } & Government Stability & $\begin{array}{l}\text { Government Unity } \\
\text { Legislative Strength } \\
\text { Popular Support }\end{array}$ \\
\hline & & Socioeconomic Conditions & $\begin{array}{l}\text { Unemployment } \\
\text { Consumer Confidence } \\
\text { Poverty }\end{array}$ \\
\hline & & Investment Profile & $\begin{array}{l}\text { Contract Viability/Expropriation Profits Repatriation } \\
\text { Payment Delays }\end{array}$ \\
\hline & & Internal Conflict & $\begin{array}{l}\text { Civil War/Coup Threat } \\
\text { Terrorism/Political Violence } \\
\text { Civil Disorder }\end{array}$ \\
\hline & & External Conflict & $\begin{array}{l}\text { War } \\
\text { Cross-Border Conflict } \\
\text { Foreign Pressures }\end{array}$ \\
\hline & & Corruption & \\
\hline & & Military in Politics & \\
\hline & & Religious Tensions & \\
\hline & & Law and Order & $\begin{array}{l}\text { The strength and impartiality of the legal system } \\
\text { An assessment of popular observance of the law }\end{array}$ \\
\hline & & Ethnic Tensions & \\
\hline & & Democratic Accountability & $\begin{array}{l}\text { Alternating Democracy } \\
\text { Dominated Democracy } \\
\text { De Facto One-Party State } \\
\text { De Jure One-Party State } \\
\text { Autarchy }\end{array}$ \\
\hline & & Bureaucracy Quality & \\
\hline & Economic Risk & & $\begin{array}{l}\text { GDP per Capita } \\
\text { Real GDP Growth } \\
\text { Annual Inflation Rate } \\
\text { Budget Balance \% GDP } \\
\text { Current Account \% GDP }\end{array}$ \\
\hline & Financial Risk & & $\begin{array}{l}\text { Foreign Debt } \% \text { GDP } \\
\text { Debt Service } \% \text { XGS } \\
\text { Current Account as \% XGS } \\
\text { Net Liquidity in Months } \\
\text { Exchange Rate Stability }\end{array}$ \\
\hline \multirow[t]{3}{*}{$\begin{array}{l}\text { International Business } \\
\text { Compass (IBC) }\end{array}$} & $\begin{array}{l}\text { Economic } \\
\text { conditions }\end{array}$ & $\begin{array}{l}\text { Per capita income } \\
\text { Public debt } \\
\text { Per-capita FDI inflows } \\
\text { Inflation } \\
\text { Business freedom } \\
\text { Infrastructure } \\
\text { Aggregate tax rate } \\
\text { Market potential }\end{array}$ & $\begin{array}{l}\text { Market attractiveness } \\
\text { Population } \\
\text { Inflation } \\
\text { Consumption expenditure per capita } \\
\text { Political stability } \\
\text { Infrastructure } \\
\text { Trade freedom }\end{array}$ \\
\hline & $\begin{array}{l}\text { Political-legal } \\
\text { conditions }\end{array}$ & $\begin{array}{l}\text { Political stability } \\
\text { Regulatory quality } \\
\text { Rule of law } \\
\text { Control of corruption } \\
\text { Trade freedom } \\
\text { Investment freedom }\end{array}$ & \multirow{2}{*}{$\begin{array}{l}\text { Production location attractiveness: } \\
\text { Aggregate tax rate } \\
\text { Infrastructure } \\
\text { Market potential } \\
\text { Costs of labour } \\
\text { Rule of law } \\
\text { Labour freedom } \\
\text { Freedom of investment }\end{array}$} \\
\hline & $\begin{array}{l}\text { Socio-cultural } \\
\text { conditions }\end{array}$ & $\begin{array}{l}\text { Population growth } \\
\text { Unemployment rate } \\
\text { Consumption expenditures per } \\
\text { capita } \\
\text { Health } \\
\text { Education } \\
\text { Labour freedom }\end{array}$ & \\
\hline $\begin{array}{l}\text { Global } \\
\text { Competitiveness } \\
\text { Index }\end{array}$ & Institutions & $\begin{array}{l}\text { Public institutions } \\
\text { Private institutions }\end{array}$ & $\begin{array}{l}\text { 1) Property rights } \\
\text { Ethics and corruption } \\
\text { Undue influence } \\
\text { 2) Public-sector performance } \\
\text { Security } \\
\text { Corporate ethics }\end{array}$ \\
\hline
\end{tabular}


Continuation of Table 1

\begin{tabular}{|c|c|c|c|}
\hline 1 & 2 & 3 & 4 \\
\hline & Infrastructure & $\begin{array}{l}\text { Transport infrastructure } \\
\text { Electricity and telephony } \\
\text { infrastructure }\end{array}$ & $\begin{array}{l}\text { 1) Quality of overall infrastructure Quality of roads } \\
\text { Quality of railroad infrastructure } \\
\text { Quality of port infrastructure } \\
\text { Quality of air transport infrastructure } \\
\text { Available airline seat kilometres } \\
\text { 2) Quality of electricity supply } \\
\text { Mobile telephone subscriptions } \\
\text { Fixed telephone lines }\end{array}$ \\
\hline & $\begin{array}{l}\text { Macroeconomic } \\
\text { environment }\end{array}$ & & $\begin{array}{l}\text { Government budget balance } \\
\text { Gross national savings } \\
\text { Inflation } \\
\text { Government debt } \\
\text { Country credit rating }\end{array}$ \\
\hline & $\begin{array}{l}\text { Health and } \\
\text { primary } \\
\text { education }\end{array}$ & $\begin{array}{l}\text { 1) Health } \\
\text { 2) Primary education }\end{array}$ & $\begin{array}{l}\text { 1) Business impact of malaria } \\
\text { Malaria incidence } \\
\text { Business impact of tuberculosis } \\
\text { Tuberculosis incidence } \\
\text { Business impact of HIV/AIDS } \\
\text { HIV prevalence } \\
\text { Infant mortality } \\
\text { Life expectancy } \\
\text { 2) Quality of primary education } \\
\text { Primary education enrolment rate }\end{array}$ \\
\hline & $\begin{array}{l}\text { Higher } \\
\text { education and } \\
\text { training }\end{array}$ & $\begin{array}{l}\text { 1) Quantity of education } \\
\text { 2) Quality of education } \\
\text { 3) On-the-job training }\end{array}$ & $\begin{array}{l}\text { 1)Secondary education enrolment rate } \\
\text { Tertiary education enrolment rate } \\
\text { 2) Quality of the educational system } \\
\text { Quality of math and science education } \\
\text { Quality of management schools } \\
\text { Internet access in schools } \\
\text { 3) Local availability of specialized research and } \\
\text { training services } \\
\text { Extent of staff training }\end{array}$ \\
\hline & $\begin{array}{l}\text { Goods market } \\
\text { efficiency }\end{array}$ & $\begin{array}{l}\text { 1) Domestic competition } \\
\text { 2) Foreign competition } \\
\text { 3) Quality of demand conditions }\end{array}$ & $\begin{array}{l}\text { 1) Intensity of local competition } \\
\text { Extent of market dominance } \\
\text { Effectiveness of anti-monopoly policy } \\
\text { Effect of taxation on incentives to invest } \\
\text { Total tax rate } \\
\text { Number of procedures required to start a business } \\
\text { Time required to start a business } \\
\text { Agricultural policy costs } \\
\text { 2) Prevalence of trade barriers Trade tariffs } \\
\text { Prevalence of foreign ownership Business impact of } \\
\text { rules on FDI } \\
\text { Burden of customs procedures } \\
\text { Imports as a percentage of GDP } \\
\text { 3) Degree of customer orientation } \\
\text { Buyer sophistication }\end{array}$ \\
\hline & $\begin{array}{l}\text { Labour market } \\
\text { efficiency }\end{array}$ & $\begin{array}{l}\text { 1) Flexibility } \\
\text { 2) Efficient use of talent }\end{array}$ & $\begin{array}{l}\text { 1) Cooperation in labour-employer relations } \\
\text { Flexibility of wage determination } \\
\text { Hiring and firing practices Redundancy costs } \\
\text { Effect of taxation on incentives to work } \\
\text { 2) Pay and productivity } \\
\text { Reliance on professional management } \\
\text { Country capacity to retain talent } \\
\text { Country capacity to attract talent } \\
\text { Female participation in labour force }\end{array}$ \\
\hline & $\begin{array}{l}\text { Financial market } \\
\text { development }\end{array}$ & $\begin{array}{l}\text { 1) Efficiency } \\
\text { 2) Trustworthiness and } \\
\text { confidence }\end{array}$ & $\begin{array}{l}\text { 1) Financial services meeting business needs } \\
\text { Affordability of financial services } \\
\text { Financing through local equity market } \\
\text { Ease of access to loans } \\
\text { Venture capital availability } \\
\text { 2) Soundness of banks } \\
\text { Regulation of securities exchanges } \\
\text { Legal rights index }\end{array}$ \\
\hline
\end{tabular}


Ending of Table 1

\begin{tabular}{|c|c|c|c|}
\hline 1 & 2 & 3 & 4 \\
\hline & $\begin{array}{l}\text { Technological } \\
\text { readiness }\end{array}$ & $\begin{array}{l}\text { 1) Technological adoption } \\
\text { 2) ICT use }\end{array}$ & $\begin{array}{l}\text { 1) Availability of latest technologies } \\
\text { Firm-level technology absorption } \\
\text { FDI and technology transfer } \\
\text { 2) Internet users } \\
\text { Broadband Internet subscriptions } \\
\text { Internet bandwidth } \\
\text { Mobile broadband subscriptions } \\
\text { Mobile telephone subscriptions } \\
\text { Fixed telephone lines }\end{array}$ \\
\hline & Market size & $\begin{array}{l}\text { 1) Domestic market size } \\
\text { 2) Foreign market size }\end{array}$ & $\begin{array}{l}\text { 1) Domestic market size } \\
\text { 2) Foreign market size }\end{array}$ \\
\hline & $\begin{array}{l}\text { Business } \\
\text { sophistication }\end{array}$ & & $\begin{array}{l}\text { Local supplier quantity } \\
\text { Local supplier quality } \\
\text { State of cluster development } \\
\text { Nature of competitive advantage } \\
\text { Value chain breadth } \\
\text { Control of international distribution } \\
\text { Production process sophistication } \\
\text { Extent of marketing } \\
\text { Willingness to delegate authority } \\
\text { Reliance on professional management }\end{array}$ \\
\hline & Innovation & & $\begin{array}{l}\text { Capacity for innovation } \\
\text { Quality of scientific research institutions } \\
\text { Company spending on R\&D } \\
\text { University-industry collaboration in R\&D } \\
\text { Government procurement of advanced technology } \\
\text { products } \\
\text { Availability of scientists and engineers } \\
\text { PCT patent applications } \\
\text { Intellectual property protection }\end{array}$ \\
\hline
\end{tabular}

Source: [3; 4, p. 53; 5, p. 317-324]

Helmut (2014), based on the survey of 87 high-level managers of global shareholders in various industries such as the automotive, chemical, pharmaceutical, clothing and food industries, claims on the importance of the five major groups of macroeconomic factors: political, legal, economic, social, technological and intercultural and found that the most influential are political factors, then economic, social, technical, and then intercultural [11, p. 29-40].

A secondary study was also conducted on the country's macroeconomic indicators for four important economies in the world, namely Central Europe, Eastern Europe, the USA, and China. The data was collected from various official and well-known institutions. The results of the analysis are ambiguous. In China, political and economic factors are the least significant. For Central European countries, an important technical environment and infrastructure, as well as the social sphere. Eastern European countries are attractive to foreign investors in terms of the technical environment [3].
Conclusion. Summarizing all the above, it could be concluded that the investment attractiveness of the country grounds on the micro level basis, starting from the attractiveness of the enterprise, then transforming into the attractiveness of the industry, area, and country. The main determinant for any investment decision, especially on the micro level, is the ROI indicator.

There are many factors that affect the inflow of investment. International ratings cover a major number of them, providing an objective assessment.

The main factors are determined by the purpose of the investment. And the pivotal factors could be the market, its size, efficiency, quality of labour, openness; political and economic stability, reliability of state institutions, exchange rate, internal and external conflicts. For developing countries, Ukraine for instance, the identification of the key factor and assessing method is crucial to determine an accurate estimation of the investment attractiveness and to enhance it.

\section{References:}

1. Korenyuk Petr, Kopyl Elena (2018) Kontseptualni pidkhody ta metody vyznachennya investytsiynoyi pryvablyvosti natsionalnoyi ekonomik [Conceptual approaches and methods for determining the investment attractiveness of national economies] Economic Journal of Lesya Ukrainka Eastern European National University, vol. 2 (14), pp. 56-62

2. Dovhan Yu.V. (2016) Otsinka investytsiinoi pryvablyvosti (na prykladi Ukrainy, Vinnytskoi oblasti ta oliino-zhyrovoho pidkompleksu) [Assessment of investment attractiveness (for example, Ukraine, Vinnytsia region and oil and fat sub-complex)] Finance, accounting, banks, vol. 1 (21), pp. 235-244.

3. The PRS Group. International Country Risk Guide Methodology. URL : https://www.prsgroup.com/wp-content/uploads/2012/11/ icrgmethodology.pdf (accessed 15.07.2019)

4. Theodor Friederiszick, Marcel Stapke, André Wolf. BDO International Business Compass. Hamburg. 2018. 53 pp.

5. The Global Competitiveness Report 2017-2018 / ed. Prof. Klaus Schwab: World Economic Forum. 2017. 379 pp.

6. Erdal Demirhan, Mahmut Masca. Determinants of foreign direct investment flows to developing countries: A cross-sectional analysis. Prague Economic Papers. 2008. № 4. 356-369 pp. 
7. Shaukat Ali. Wei Guo. Determinants of FDI in China. Journal of Global Business and Technology. Volume 1. № 2, Fall 2005. 21-33 pp.

8. Federica Custorella. The impact of globalization on FDI: An empirical analysis of the FDI determinants in China : Master's Thesis : EKHR81 "Master's Programme in International Economics with a focus on China"; Lund University School of Economics and Management. Sweden. June 2017. 48 pp.

9. Bolaev A. V. (2014) Privlechenie pryamykh inostrannykh investitsiy kak faktor vnedreniya zarubezhnykh tekhnologiy v straneretsipiente $\mathrm{v}$ usloviyakh ekonomicheskoy globalizatsii [Attracting direct foreign investment as a factor in the introduction of foreign technology in the recipient country in the context of economic globalization] Upravlenie ekonomicheskimi sistemami: elektronnnyy nauchnyy zhurnal [Economic Systems Management: an electronic scientific journal] (electronic journal), vol. 4, no 64. Available at: https://cyberleninka.ru/article/n/privlechenie-pryamyh-inostrannyh-investitsiy-kak-faktor-vnedreniya-zarubezhnyhtehnologiy-v-strane-retsipiente-v-usloviyah (accessed 08 August 2019)

10. Antonios Zairis. The course of foreign direct investment in the Greek economy. East-West Journal of Economics and Business. Vol. XIX. No 2. 2016. 11-32 pp.

11. Helmut Birnleitner. Attractiveness of Countries for Foreign Direct Investments from the Macro-Economic Perspective. Proceedings of FIKUSZ '14 Symposium for Young Researchers : materials of scientific-practical. Conf. by the Óbuda University Budapest. 2014. $29-40 \mathrm{pp}$.

1. Коренюк Петр, Копил Елена. Концептуальні підходи та методи визначення інвестиційної привабливості національної економік. Економічний часопис Східноєвропейського національного університету імені Лесі Украӥнки. 2018. № 2 (14) C. 56-62.

2. Довгань Ю.В. Оцінка інвестиційної привабливості (на прикладі України, Вінницької області та олійно-жирового підкомплексу). Фінанси, облік, банки. 2016. № 1 (21). С. 235 - 244

3. The PRS Group. International Country Risk Guide Methodology. URL : https://www.prsgroup.com/wp-content/uploads/2012/11/ icrgmethodology.pdf (дата звернення: 15.07.2019)

4. Theodor Friederiszick, Marcel Stapke, André Wolf. BDO International Business Compass. Hamburg. 2018. 53 pp.

5. The Global Competitiveness Report 2017-2018 / ed. Prof. Klaus Schwab: World Economic Forum. 2017. 379 pp.

6. Erdal Demirhan, Mahmut Masca. Determinants of foreign direct investment flows to developing countries: A cross-sectional analysis. Prague Economic Papers. 2008. № 4. 356-369 pp.

7. Shaukat Ali. Wei Guo. Determinants of FDI in China. Journal of Global Business and Technology. Volume 1. № 2, Fall 2005. 21-33 pp.

8. Federica Custorella. The impact of globalization on FDI: An empirical analysis of the FDI determinants in China : Master's Thesis : EKHR81 "Master's Programme in International Economics with a focus on China"; Lund University School of Economics and Management. Sweden. June 2017. 48 pp.

9. Болаев А. В. Привлечение прямых иностранных инвестиций как фактор внедрения зарубежных технологий в странереципиенте в условиях экономической глобализации. Управление экономическими системами: электроннный научный журнал. 2014. 4 (64).

10. Antonios Zairis. The course of foreign direct investment in the Greek economy. East-West Journal of Economics and Business. Vol. XIX. No 2. 2016. 11-32 pp.

11. Helmut Birnleitner. Attractiveness of Countries for Foreign Direct Investments from the Macro-Economic Perspective. Proceedings of FIKUSZ '14 Symposium for Young Researchers : materials of scientific-practical. Conf. by the Óbuda University Budapest. 2014. 29-40 pp.

\section{МЕТОДИ ОЦІНКИ ІНВЕСТИЦЙНОЇ ПРИВАБЛИВОСТІ КРАЇНИ}

Анотація. В умовах глобалізації зростає взаємозалежність країн та економічний розрив між ними. Таким чином, з'являються групи країн, які мають зростаючу потребу в іноземних інвестиціях у різних галузях економіки. У той же час рівень економічної привабливості та готовність галузей до інвестицій відрізняється в розвинених країнах та країнах, що розвиваються. Таке положення є першою причиною продовження дослідження даної теми. Більш того, нові економічні тенденції прогнозують майбутню кризу, яка має розпочатися в Америці. Короткі американські облігації стають вигіднішими, ніж довгі. Аналітики порівнюють рівень прибутковості між десятирічними облігаціями (еталонними) і більш короткими. Якщо прибутковість "коротких" вище, ніж довгих - 3 інтервалом в 300 днів можна очікувати наступ рецесії. Аналогічна ситуація склалася в 2008, 2001, 1990 роках. В 2018 році, інверсія відбулася між 10-річними і 2-річними облігаціями, але дане співвідношення не цілком відображає вказане вище правило. Важливим є співвідношення між тримісячними і 10-річними облігаціями. Третя причина продовження дослідження даної теми $є$ важливою для нашої країни. Адже одним із ключових факторів інвестиційної привабливості є позики МВФ. Присутність МВФ у списку кредиторів країни підвищує ії інвестиційну привабливість. Співпраця з Міжнародним валютним фондом говорить про те, що країна-позичальник дотримується принципів ліберальної економіки, що допомагає залучати інвесторів. 3 моменту отримання траншів від МВФ Україна обговорює свою інвестиційну привабливість. Тому існує потреба у правильному виборі методу оцінки та факторів, особливо сьогодні. У цій статті автори розглядають існуючі методи кількісного вимірювання та оцінки інвестиційної привабливості економіки на мікро-, мезо- та макрорівні. Автори розглядають показники, які використовуються для оцінки привабливості інвестицій на цих рівнях та створюють взаємозв'язку між мікро та макрорівнями. Більша частина досліджень зосереджена на макрорівні. У статті розглядаються фактори, які застосовують міжнародні рейтингові агенції та індекси для оцінки інвестиційної привабливості країни, а також деякі практичні дослідження впливу окремих факторів на країни. Спираючись на приклади, автори розподіляють, які 3 них мають позитивний та негативний вплив.

Ключові слова: фактори інвестицій, привабливість країни, методи інвестиційної оцінки, інвестиції, міжнародні індекси. 


\section{МЕТОДЫ ОЦЕНКИ ИНВЕСТИЦИОННОЙ ПРИВЛЕКАТЕЛЬНОСТИ СТРАНЫ}

Аннотация. В условиях глобализации возрастает взаимозависимость стран и экономический разрыв между ними. Таким образом, появляются группы стран, которые имеют растущую потребность в иностранных инвестициях в различных отраслях экономики. В то же время уровень экономической привлекательности и готовность отраслей к инвестициям отличается в развитых странах и развивающихся странах. Такое положение является первой причиной продолжения исследования данной темы. Более того, новые экономические тенденции прогнозируют вероятность возникновения кризиса, который должен начаться в Америке. Короткие американские облигации становятся более выгодными, чем длинные. Аналогичная ситуация сложилась в 2008, 2001, 1990 годах. Третья причина продолжения исследования данной темы является важной для нашей страны. Так как одним из ключевых факторов инвестиционной привлекательности являются займы МВФ. Присутствие МВФ в списке кредиторов страны повышает ее инвестиционную привлекательность. Сотрудничество с Международным валютным фондом говорит о том, что страна-заемщик придерживается принципов либеральной экономики, помогает привлекать инвесторов. С момента получения траншей от МВФ Украина все еще оценивает свою инвестиционную привлекательность. Поэтому существует потребность в правильном выборе метода оценки и факторов, особенно сегодня. В этой статье авторы рассматривают существующие методы количественного измерения и оценки инвестиционной привлекательности экономики на микро-, мезо- и макроуровне. Авторы рассматривают показатели, используемые для оценки привлекательности инвестиций на этих уровнях и создают взаимосвязи между микро и макроуровнями. Большая часть исследований сосредоточена на макроуровне. В статье рассматриваются факторы, которые применяют международные рейтинговые агентства и индексы для оценки инвестиционной привлекательности страны, а также некоторые практические исследования влияния отдельных факторов на экономику страны. Авторы распределяют, которые из них имеют позитивное и негативное влияние.

Ключевые слова: факторы инвестиций, привлекательность страны, методы инвестиционной оценки, инвестиции, международные индексы. 